\title{
Improve Learning Results Using The Problem Based Learning Model
}

\author{
Ariyanto \\ SDIT Nurul Ilam Butuh \\ ari662005007@gmail.com
}

\section{Article History}

accepted 01/11/2020

approved 08/11/2020

published 15/11/2020

\begin{abstract}
The purpose of this study was to improve learning outcomes in theme 4 using the Problem Based Learning Model. The research cond ucted was a Classroom Action Research (PTK) consisting of three cycles, with each cycle consisting of a pre-test meeting. The stages of each cycle are planning, implementing, observing and reflecting. Each meeting was conducted with a post test to determine the development of students. In the first cycle the students who completed after carrying out the post test were $66.66 \%$. In the second cycle students who completed after carrying out the post test were 92\%. In cycle III the students who completed after carrying out the post test were 100\%. These results indicate that the Project Based Learning (PjBL) learning model can improve student learning outcomes, especially the theme 4 Class V at SDIT Nurul Islam Butuh.

Keywords: Learning Outcomes, Problem Based Learning (PBL)
\end{abstract}

\section{Abstrak}

Tujuan dari penelitian ini adalah untuk meningkatkan hasil belajar tema 4 menggunakan Model Problem Based Learning. Penelitian yang dilakukan adalah Penelitian Tindakan Kelas (PTK) sebanyak tiga siklus, dengan setiap siklusnya terdiri dari sebuah pertemuan yang sebelumnya diadakan pretest dulu. Tahapan setiap siklusnya adalah perencanaan, pelaksanaan, observasi dan refleksi. Setiap pertemuan dilakukan post test untuk mengetahui perkembangan peserta didik. Pada siklus I peserta didik yang tuntas setelah melaksanakan post test sebesar $66,66 \%$. Pada siklus II peserta didik yang tuntas setelah melaksanakan post test sebesar $92 \%$. Pada siklus III peserta didik yang tuntas setelah melaksanakan post test sebesar $100 \%$. Hasil ini menunjukan bahwa model pembelajaran Project Based Learning (PjBL) dapat meningkatkan hasil belajar peserta didik khususnya tema 4 Kelas V di SDIT Nurul Islam Butuh.

Kata kunci: Hasil belajar, Problem Based Learning (PBL)

Social, Humanities, and Education Studies (SHEs): Conference Series https://jurnal.uns.ac.id/shes

p-ISSN 2620-9284

e-ISSN 2620-9292 


\section{PENDAHULUAN}

Pendidikan Indonesia adalah seluruh pendidikan yang diselenggarakan di Indonesia, baik itu secara terstruktur maupun tidak terstruktur. Secara terstruktur, pendidikan di Indonesia menjadi tanggung jawab Kementerian Pendidikan dan Kebudayaan Republik Indonesia (Kemdikbud), dahulu bernama Departemen Pendidikan Nasional Republik Indonesia (Depdiknas). Di Indonesia, semua penduduk wajib mengikuti program wajib belajar pendidikan dasar selama sembilan tahun, enam tahun di sekolah dasar/madrasah ibtidaiyah dan tiga tahun di sekolah menengah pertama/madrasah tsanawiyah. Saat ini, pendidikan di Indonesia diatur melalui Undang-Undang Nomor 20 Tahun 2003 tentang Sistem Pendidikan Nasional.

Salah satu jenjang pendidikan adalah Sekolah dasar (SD). Masa usia Sekolah Dasar merupakan periode emas (golden age) bagi perkembangan anak untuk memperoleh proses pendidikan. Periode ini adalah tahun-tahun berharga bagi seorang anak untuk mengenali berbagai macam fakta di lingkungannya sebagai stimulans terhadap perkembangan aspek kepribadian, kognitif, psikososial, maupun moralnya.

Untuk itu pendidikan anak untuk usia Sekolah Dasar dalam bentuk pemberian rangsangan-rangsangan (stimulasi) dari lingkungan terdekat sangat diperlukan untuk mengoptimalkan kemampuan anak.

Pembentukan kemampuan siswa di sekolah dipengaruhi oleh proses belajar yang ditempuhnya. Proses belajar akan terbentuk berdasarkan pandangan dan pemahaman guru tentang karakteristik siswa dan juga hakikat pembelajaran.

Proses pembelajaran pada kurikulum 2013 diawali kegiatan mengamati oleh siswa dengan cara melihat, membaca, mendengar dan menyimak tentang masalah yang berkaiatan dengan materi pelajaran. Setelah siswa mengamati, siswa dapat bertanya tentang apa yang dilihat, dibaca, didengar dan disimak baik secara lisan maupun tulisan. Langkah selanjutnya kegiatan menganalisis dengan cara mengumpulkan informasi, menghubungkan informasi yang didapat oleh siswa, dan menentukan keterkaitan antara informasi yang satu dengan lainnya (mengolah informasi). Kegiatan akhir yang dilakukan oleh siswa adalah mengomunikasikan hasil pengamatan yang telah dibuat oleh siswa. Dalam kurikulum 2013 pembelajaran berbasis tematik.

Menurut Brunner dalam Sugandi (2007:36) ada empat hal pokok penting yang perlu diperhatikan yaitu peranan pengalaman struktur pengetahuan, kesiapan mempelajari sesuatu, intuisi dan cara membangkitkan motivasi belajar. Guru dituntut untuk bisa membawa peserta didik ke dalam dunia yang menyenangkan di dalam pembelajaran. Peserta didik yang merasa nyaman dan senang, maka akan berani untuk aktif dan akan mempunyai motivasi lebih untuk terus belajar. Peserta didik yang mempunyai motviasi lebih untuk belajar biasanya akan mendapatkan hasil belajar yang baik. Guru sebagai pemegang proses pembelajaran harus bisa menyajikan hal terbaik. Model pembelajaran yang digunakan haruslah sesuai dengan materi yang sedang diajarkan, karena tidak semua model pembelajaran dapat digunakan untuk semua materi. Pemilihan model pembelajaran akan mendukung hasil pembelajaran yang akan dicapai. Semua muatan pelajaran membutuhkan penerapan model pembelajaran.

Peneliti memilih SDIT Nurul Islam Butuh karena dalam pembelajaran hanya menitik beratkan penguasaan konsep saja. Guru masih menggunakan metode konvensional secara monoton dalam kegiatan pembelajaran di kelas, sehingga suasana belajar terkesan kaku dan didominasi oleh guru. Guru menyampaikan materi dengan metode ceramah, dimana siswa hanya duduk, mencatat, dan mendengarkan apa yang disampaikannya, sehingga ketika siswa diminta untuk bertanya oleh guru banyak yang tidak melakukannya. Hal ini karena siswa kurang termotivasi untuk lebih aktif mengutarakan pendapat, ide, gagasan, pertanyaan dan kesulitan-kesulitan 
maupun hal-hal yang belum dipahami selama pelajaran. Suasana pembelajaran menjadi tidak kondusif, sehingga hasil belajar masih rendah.

Untuk meningkatkan Prestasi belajar siswa salah satunya adalah penggunaan metode yang sesuai. Metode problem based learning merupakan salah satu metode pembelajaran yang sesuai dengan abad 21 , dimana dapat nenumbuhkan anak untuk perpikir kritis dan kreatif.

Oleh sebab itu, penulis melakukan penelitian tindakan kelas yang berjudul "Upaya Meningkatkan Hasil Belajar Tema 4 Menggunakan Model Problem Based Learning Pada Siswa Kelas VD"

Finkle and Torp (1995) dalam Aris Shoimin (2014:130) menyatakan bahwa: Problem Based Learning merupakan pengembangan kurikulum dan sistem pengajaran yang mengembangkan secara stimulan strategi pemecahan masalah dan dasar-dasar pengetahuan dan keterampilan dengan menempatkan para peserta didik dalam peran aktif sebagai pemecah permasalahan sehari-hari yang tidak terstruktur dengan baik.

Sedangkan menurut Kamdi (2007:77) berpendapat bahwa: Model Problem Based Learning diartikan sebagai sebuah model pembelajaran yang didalamnya melibatkan siswa untuk berusaha memecahkan masalah dengan melalui beberapa tahap metode ilmiah sehingga siswa diharapkan mampu mempelajari pengetahuan yang berkaitan dengan masalah tersebut dan sekaligus siswa diharapkan akan memilki keterampilan dalam memecahkan masalah.

Dari uraian di atas dapat disimpulkan bahwa metode based learning adalah pendekatan pembelajaran yang berusaha menerapkan masalah yang terjadi dalam dunia nyata sebagai sebuah konteks bagi para siswa dalam berlatih bagaimana cara berfikir kritis dan mendapatkan keterampilan dalam pemecahan masalah.

Problem Based Learning (PBL) adalah model pengajaran yang bercirikan adanya permasalahan nyata sebagai konteks untuk para peserta didik belajar berfikir kritis dan keterampilan memecahkan masalah, dan memperoleh pengetahuan (Duch,1995).

\section{METODE}

Penelitian ini adalah penelitian tindakan kelas (Classroom Action Research) dengan menerapkan model pembelajaran Project Based Learning. Menurut Hopkins (1993), penelitian tindakan kelas diawali dengan perencanaan tindakan (Planning), penerapan tindakan (action), mengobservasi dan mengevaluasi proses dan hasil tindakan (Observation and evaluation).

Subyek penelitian adalah siswa kelas VD SDIT Nurul Islam Butuh tahun pelajaran 2020/2020. Adapun yang diteliti adalah aktivitas peserta didik dalam mengikuti proses pembelajaran, tanggapan peserta didik, dan hasil belajar peserta didik. Penelitian dilakukan menggunakan 3 siklus yang sebelumnya dilakukan pretest. Siklus I dilaksanakan pada tanggal 19 sampai 24 Oktober 2020. Siklus II dilaksanakan pada tanggal 26 Oktober sampai 4 November 2020. Siklus III dilaksanakan pada tanggal 10 sampai 14 November 2020. Data yang diambil berupa data kuantutatif dan data kualitatif. Data kuantitif berupa hasil evaluasi belajar Tema 4 dengan menggunakan metode Problem Based Learning, sedangkan data kualitatif di peroleh dari hasil observasi selama proses pembelajaran berlangsung. Teknik analisis data yang digunakan dalam penelitian ini adalah deskriptif kuantitatif dan kualitatif. Data kualitatif di peroleh dari observasi terhadap aktivitas siswa, guru, dan hasil belajar berupa ranah psikomotorik (keterampilan proses pengamatan), serta ranah afektif (sikap ilmiah siswa) selama proses pembelajaran berlangsung. Sedangkan data kualitatif dikumpulkan melalui tes yang dilaksanakan setiap akhir siklus. 


\section{HASIL DAN PEMBAHASAN}

Untuk mengetahui kemampuan awal siswa, dalam penelitian ini siswa terlebih dahulu diberi Pre Test. Pre Test ini bertujuan untuk mengetahui kemampuan awal siswa. Dari nilai hasil Pre Test yang di berikan peneliti tentang peristiwa alam, hasil yang diperoleh belum memuaskan. Kesulitan tersebut dapat dilihat dari kesalahan siswa dalam menjawab soal-soal Pre Test.

Adapun kemampuan siswa terlebih dahulu di berikan tindakan (hasil tes awal) dapat dilihat pada tabel berikut:

Tabel 1. Data Hasil Nilai Pre Test (Tes Awal)

\begin{tabular}{lcc}
\multicolumn{1}{c}{ Pretest } & $\begin{array}{c}\text { Jumlah } \\
\text { anak }\end{array}$ & $\begin{array}{c}\text { pers } \\
\text { en }\end{array}$ \\
\hline Jumlah siswa tuntas & 12 & $50 \%$ \\
Jumlah siswa tidak tuntas & 12 & $50 \%$ \\
\hline \multicolumn{1}{c}{ Rata-rata nilai siswa } & \multicolumn{2}{c}{72} \\
\hline
\end{tabular}

Berdasarkan Tabel 1, peserta didik yang tuntas berjumlah 12 orang dari Kriteria Ketuntasan Minimal (KKM) sebesar 75 dengan persentase ketuntasan 50\%. Sedangkan siswa yang tidak tuntas berjumlah 12 orang dan jika di persentasekan yaitu 50\%. Dari keseluruhan peserta didik diperoleh rata-rata kelas 72 . Hal ini menunjukkan bahwa rata-rata kelas masih di bawah KKM.

Berdasarkan refleksi pada hasil pretest maka akan dilakukan tindakan pertama (siklus I) dikarenakan belum mencapai ketuntasan klasikal yang diharapkan. Siklus I membahas materi Tema 4 Sehat Itu Penting, Subtema 3 Organ Peredaran Darah pada Manusia, Pembelajaran 1. Tahap ini dilakukan untuk menganalisa dan memberikan arti terhadap data yang diperoleh dan upaya untuk memperjelas dalam menetapkan kesimpulan dan tindakan yang telah dilakukan. Hasil refleksi ini sebagai rujukan untuk melaksanakan perbaikan-perbaikan pada pelaksanaan pembelajaran selanjutnya. Berikut ini adalah hasil belajar peserta didik pada siklus I yang bisa dilihat pada tabel berikut.

Tabel 2. Data Hasil Nilai Post Test Siklus I

\begin{tabular}{lcc}
\hline \multicolumn{1}{c}{ Siklus 1 } & $\begin{array}{c}\text { Jumlah } \\
\text { anak }\end{array}$ & $\begin{array}{c}\text { pers } \\
\text { en }\end{array}$ \\
\hline Jumlah siswa tuntas & 16 & $\begin{array}{c}6 \% \\
66,6 \\
33,3 \\
\text { Jumlah siswa tidak tuntas }\end{array}$ \\
& 8 & $4 \%$ \\
\hline Rata-rata nilai siswa & \multicolumn{2}{c}{78} \\
\hline
\end{tabular}

Berdasarkan hasil evaluasi bahwa hasil belajar siswa pada Tema 4 Sehat Itu Penting, dapat diketahui sebanyak 16 siswa (66.67\%) dinyatakan tuntas dan sebanyak 8 siswa (33.33\%) dinyatakan tidak tuntas dengan rata-rata kelas 78 . Berdasarkan perbandingan jumlah tersebut maka dapat dikemukakan bahwa perolehan hasil test siswa pada silus 1 Tema 4 Sehat Itu Penting belum sesuai yang diharapkan.

Berdasarkan refleksi pada hasil siklus 1 maka akan dilakukan tindakan kedua (siklus II) dikarenakan belum mencapai ketuntasan klasikal yang diharapkan. Siklus II membahas materi Tema 4 Sehat Itu Penting, Subtema 3 Organ Peredaran Darah 
pada Manusia, Pembelajaran 2. Tahap ini dilakukan untuk menganalisa dan memberikan arti terhadap data yang diperoleh dan upaya untuk memperjelas dalam menetapkan kesimpulan dan tindakan yang telah dilakukan. Hasil refleksi ini sebagai rujukan untuk melaksanakan perbaikan-perbaikan pada pelaksanaan pembelajaran selanjutnya. Berikut ini adalah hasil belajar peserta didik pada siklus II yang bisa dilihat pada tabel berikut

Tabel 3. Data Hasil Nilai Post Test Siklus I

\begin{tabular}{lcc}
\multicolumn{1}{c}{ Siklus 1 } & $\begin{array}{c}\text { Jumlah } \\
\text { anak }\end{array}$ & $\begin{array}{c}\text { pers } \\
\text { en }\end{array}$ \\
\hline Jumlah siswa tuntas & 22 & $92 \%$ \\
Jumlah siswa tidak tuntas & 2 & $8 \%$ \\
\hline Rata-rata nilai siswa & \multicolumn{2}{c}{87} \\
\hline
\end{tabular}

Berdasarkan hasil evaluasi melalui post test Siklus II membuktikan bahwa hasil belajar siswa pada Tema 4 Sehat Itu Penting dapat diketahui sebanyak 2 siswa $(8 \%)$ dinyatakan tidak tuntas dan sebanyak 22 siswa (92\%) dinyatakan tuntas dengan ratarata kelas 87 . Berdasarkan perbandingan jumlah tersebut maka dapat dikemukakan bahwa perolehan hasil post test siklus II mengalami ketuntasan pada hasil belajar siswa.

Setelah melakukan refleksi pada siklus II, maka diputuskan untuk melanjutkan pada siklus III. Hal ini dilakukan agar mengetahui sejauh mana penerapan pembelajaran Problem Based Learning tidak hanya meningkatkan tetapi juga mempertahankan hasil belajar peserta didik. Siklus II membahas materi Tema 4 Sehat Itu Penting, Subtema 3 Organ Peredaran Darah pada Manusia, Pembelajaran 5. Tahap ini dilakukan untuk menganalisa dan memberikan arti terhadap data yang diperoleh dan upaya untuk memperjelas dalam menetapkan kesimpulan dan tindakan yang telah dilakukan. Hasil refleksi ini sebagai rujukan untuk melaksanakan perbaikan-perbaikan pada pelaksanaan pembelajaran selanjutnya. Berikut ini adalah hasil belajar peserta didik pada siklus III yang bisa dilihat pada tabel berikut.

Tabel 4. Data Hasil Nilai Post Test Siklus I

\begin{tabular}{l|c|c|}
\hline \multicolumn{1}{|c|}{ Siklus 1 } & Jumlah anak & persen \\
\hline Jumlah siswa tuntas & 24 & $100 \%$ \\
Jumlah siswa tidak tuntas & 0 & $0 \%$ \\
\hline
\end{tabular}

Rata-rata nilai siswa

87

Berdasarkan hasil evaluasi melalui post test Siklus III membuktikan bahwa hasil belajar siswa pada Tema 4 Sehat Itu Penting dapat diketahui sebanyak 24 siswa ( $100 \%$ ) dinyatakan tuntas dengan rata-rata kelas 87 . Berdasarkan hasil tersebut maka dapat dikemukakan bahwa perolehan hasil post test siklus III mengalami ketuntasan pada hasil belajar siswa. Hal ini membuktikan bahwa penerapan pembelajaran Problem Based Learning tidak hanya meningkatkan tetapi juga mempertahankan hasil belajar peserta didik.

Dari tiga siklus yang sudah dilaksanakan, dapat dilihat hasil evaluasi belajar siswa Tema 4 SehaT Itu Penting SDIT Nurul Islam Butuh pada pre test, post test 
siklus I, dan post test siklus II serta post test siklus III terjadi peningkatan yang signifikan dengan pengaplikasian metode PBL (Problem Based Learning). Hal ini sesuai dengan konsep atau teori yang diungkap oleh Kamdi (2007:77) yang berpendapat bahwa: Model Problem Based Learning diartikan sebagai sebuah model pembelajaran yang didalamnya melibatkan siswa untuk berusaha memecahkan masalah dengan melalui beberapa tahap metode ilmiah sehingga siswa diharapkan mampu mempelajari pengetahuan yang berkaitan dengan masalah tersebut dan sekaligus siswa diharapkan akan memilki keterampilan dalam memecahkan masalah.

\section{SIMPULAN}

Dengan menggunakan metode PBL (Problem Based Learning) pada siswa kelas VD SDIT Nurul Islam Butuh pembelajaran siswa lebih meningkat dengan di lihat dari peningkatan hasil belajar siswa, yakni pada awal pratindakan hasil belajar siswa mencapai ketuntasan 50\%. Kemudian setelah di lakukan posttes (siklus I) hasil belajar mencapai $66.67 \%$. Selanjutnya pada post tes (siklus II) hasil belajar siswa mencapai $92 \%$. Terakhir pada post test (siklus III) hasil belajar siswa mencapai 100\%. Dapat di lihat dari pembelajaran sebelum dan sesudah dilakukan dengan metode PBL, hasil belajar siswa mengalami peningkatan. Dalam proses pembelajaran Tema 4 Sehat Itu Penting dengan menggunakan metode PBL, siswa lebih aktif,dan siswa dapat menemukan masalah yang berkaitan organ peredaran darah. Kemudian siswa dapat menemukan cara memelihara organ peredaran darah dan siswa mampu berfikir secara kritis. Dengan demikian dapat disimpulkan bahwa dengan metode PBL dalam pembelajaran dapat meningkatkan hasil belajar siswa pada Tema 4 Sehat Itu Penting dikelas VD di SDIT Nurul Islam Butuh. Berdasarkan penelitian yang telah dilaksanakan salah satu model pembelajaran yang harus dikuasai guru adalah PBL karena model ini sangat cocok digunakan untuk meningkatkan hasil belajar siswa dan dapat dijadikan alternatif dalam proses belajar mengajar khususnya pada Tema 4 Sehat Itu Penting.

\section{DAFTAR PUSTAKA}

Depdiknas. 2006. Bunga Rampai Keberhasilan Guru dalam Pembelajaran (SMA, SMK, dan SLB). Jakarta: Depdiknas.

Kamdi, W dkk. 2007. Model-Model Pembelajaran Inovatif. Universitas Negeri Malang. Malang.

Kemmis and Taggart. (1990). The Action Research Planner. Victorio. Deakin. Univ Press.

Kunandar. 2011 Langkah Mudah Penelitian Tindakan Kelas, Jakarta : PT. Rajawali Pers

Masnur, Muslich. 2011. Melaksanakan PTK Itu Mudah, Jakarta : Bumi Aksara.

Shoimin, Aris. 2014. 68 Model Pembelajaran Inovatif dalam Kurikulum 2013. Yogyakarta: Ar-ruzz Media.

Sudjana, Nana. 2010. Penilaian Hasil Proses Belajar Mengajar. (Cet. XV). Bandung: PT. Ramaja Rosdakarya.

Suyadi. 2010. Panduan Penelitian Tindakan Kelas, Jogyakarta : Diva Press. 